\title{
HUBUNGAN TEKNOLOGI INFORMASI DAN KOMUNIKASI (TIK) DENGAN KELEBIHAN BERAT BADAN DI KALANGAN REMAJA SMA DI DEPOK
}

\author{
Nourmayansa Vidya Anggraini1'), Sigit Mulyono2),Agus Setiawan ${ }^{3)}$ \\ Fakultas Ilmu Kesehatan Universitas Pembangunan Nasional Veteran Jakarta ${ }^{1)}$ \\ Fakultas Ilmu Keperawatan Universitas Indonesia ${ }^{2,3)}$ \\ nourmayansa@upnvj.ac.id1), sigit@ui.ac.id²), a-setiawan@ui.ac.id³)
}

\begin{abstract}
ABSTRAK
Pola kehidupan modern didorong oleh perkembangan teknologi informasi dan komunikasi (TIK). Penelitian ini dilakukan untuk mengetahui hubungan durasi waktu penggunaan TIK dengan kelebihan berat badan di SMAIT Nurul Fikri Depok. Penelitian ini menggunakan metode cross sectional dengan jumlah sampel 217 responden. Hasil penelitian menunjukkan terdapat hubungan antara durasi waktu penggunaan akses sosial media dan typing terhadap kelebihan berat badan remaja dengan $p$ value $<0.05$. Tidak terdapat hubungan antara durasi waktu blogging terhadap kelebihan berat badan remaja. Penelitian ini dapat merekomendasikan terhadap pihak dinas pendidikan dan sekolah untuk mengaktifkan kembali peran UKS di SMA, dinas kesehatan untuk lebih mengoptimalkan program perkesmas supaya pelayanan kesehatan kepada masyarakat, khususnya remaja dapat lebih bermutu dan berkualitas, serta perawat dapat menggunakan TIK sebagai media promosi kesehatan tentang kelebihan berat badan.
\end{abstract}

Kata kunci: teknologi informasi dan komunikasi, durasi waktu, kelebihan berat badan, remaja

\section{ABSTRACT}

The pattern of modern life is driven by the development of information and communication technology (ICT). This study was conducted to determine the relationship of the duration of time the use of ICT with overweight in SMAIT Nurul Fikri Depok. The cross-sectional method was used in this study, with a sample of 217 respondents. The results showed an association between duration of use of social media access and typing to overweight adolescents with $p$-value $<0.05$. There is no relationship between the period of blogging time against adolescent overweight. Recommended to the education department and schools to reactivate the role of UKS in high school as well as health authorities to further optimize PERKEMAS program so that health care services to the public, especially teenagers can be more qualified and qualified, and also nurses can use ICT for health promotion about overweight.

Key words: information and communication technology, time duration, overweight, adolescents

Alamat korespondensi: Fakultas Ilmu Kesehatan, Jalan Limo Raya, Universitas Pembangunan Nasional Veteran Jakarta

Email: nourmayansa@upnvj.ac.id

\section{PENDAHULUAN}

Perkembangan TIK yang semakin pesat, telah membawa perubahan yang sangat besar pada kehidupan manusia ke arah pola hidup modern, mulai dari kantor, rumah, pasar, dan sekolah (Anderson, 2011). Perkembangan TIK tersebut di samping memiliki keuntungan, penggunaan TIK yang berlebihan juga memiliki kelemahan diantaranya perubahan pola hidup manusia berupa perilaku kurang gerak. Pola hidup manusia yang kurang gerak berakibat pada peningkatan risiko kelebihan berat badan (Anderson, 2011). 
Salah satu sumber untuk mengakses informasi yaitu melalui internet. Menurut data Internetlive tahun 2015, Indonesia menempati posisi 13 sebagai pengguna internet di dunia dengan jumlah pengguna sebesar 42.258 .824 orang. Sementara itu, secara lokal, jumlah pengguna internet di Jakarta mencapai 3.538.000 orang, dan di kota Depok sebesar 502.000 orang. Apabila dilihat dari profil pengakses TIK di Indonesia, remaja memiliki persentase paling tinggi yaitu sebesar 47,9\% disusul oleh usia dewasa 20,8 \% (Samuel, 2012).

Majunya teknologi menyebabkan tubuh kita kurang gerak (hypokinetic) sehingga dapat menyebabkan berbagai penyakit. Gaya hidup duduk terus-menerus dalam bekerja (sedentary) dan kurang gerak ditambah dengan adanya faktor risiko, merokok, pola makan yang tidak sehat dapat menyebabkan penyakit tidak menular seperti kelebihan berat badan. Gaya hidup masa kini di mana teknologi yang serba canggih dan modern dapat mengakibatkan seorang remaja menghabiskan 5-6 jam sehari untuk tidak melakukan aktivitas fisik yang berarti.

Beberapa kegiatan yang dilakukan ketika seseorang mengakses TIK diantaranya yaitu mengakses terhadap sosial media, typing, dan blogging (Samuel, 2012). Selain itu, menurut Samuel (2012) terdapat beberapa lokasi yang sering digunakan oleh pengguna untuk mengakses berbagai konten TIK, diantaranya adalah rumah, sekolah, kantor, mall, dan restoran. Sementara itu, dilihat dari profil pengakses TIK di Indonesia, remaja memiliki persentase paling tinggi yaitu sebesar 47,9\% disusul oleh usia dewasa 20,8\% (Samuel, 2012). Dari data sejak tahun 2005 sampai 2010, jumlah pengguna dari usia remaja tersebut meningkat hampir tiga kali lipat. Sifat remaja yang masih labil akan cenderung mengikuti perilaku, aktivitas serta gaya hidup modern teman sebayanya secara cepat. Apabila dilihat dari profil tempat tinggal (Samuel, 2012) pengguna TIK tersebar di kota-kota besar diantaranya adalah Jakarta, Depok, Bandung, Surabaya, Yogjakarta, Surabaya, dan Denpasar. Jumlah remaja pengguna TIK di kota Jakarta berjumlah 59.2\% untuk remaja.

Beberapa hasil studi menunjukkan bahwa rendahnya dan menurunnya aktivitas fisik merupakan faktor yang paling bertanggung jawab terjadinya kelebihan berat badan. Perkembangan TIK tersebut membawa perubahan yang signifikan dalam dunia kesehatan. Menurut Amy (2009) penggunaan TIK berlebihan dapat disertai peningkatan intake makanan. Perilaku kurang gerak dan peningkatan intake makanan, risiko kelebihan berat badan juga dipengaruhi oleh rate metabolisme.

Prevalensi kegemukan (obesity) di Korea Selatan berkisar dari 2,4\% di hingga 32,2\%, sedangkan di negara berkembang berkisar dari 2,4\% di Indonesia sampai 35,6\% di Saudi Arabia (Sugiyanti, 2009). Kelebihan berat badan mulai menjadi masalah kesehatan di seluruh dunia, menurut data WHO penderita kelebihan berat badan lebih dari 1,2 milyar orang (WHO, 2010).

Di Indonesia prevalensi kelebihan berat badan tahun 1989 di perkotaan $4.6 \%$ anak lakilaki dan 5.9\% anak perempuan. Empat tahun kemudian naik menjadi $6.3 \%$ untuk laki-laki dan $8 \%$ perempuan. Prevalensi kelebihan berat badan ini diperkirakan akan meningkat setiap tahunnya. Prevalensi kelebihan berat badan di Indonesia menurut data Riset Kesehatan Dasar tahun 2013, penduduk usia 13-15 tahun adalah 10.8\%, terdiri dari 8.3\% gemuk dan $2.5 \%$ sangat gemuk (obesitas). Sedangkan prevalensi gemuk pada remaja umur 16-18 tahun sebanyak $7.3 \%$ yang terdiri dari $5.7 \%$ gemuk dan $1.6 \%$ obesitas.

Penelitian sejenis dilakukan oleh San (2014) yang melakukan kajian hubungan antara Body Mass Index (BMI) dengan durasi akses terhadap internet. Objeknya yaitu mahasiswa usia 19-24 tahun dengan jumlah sampel sebesar 525 orang. Aktifitas yang dilakukan yaitu akses internet. Hasil penelitian menujukan hasil yang signifikan antara kelebihan berat badan dengan nilai Body Mass Index pada mahasiswa.

Kondisi tersebut mendorong peneliti untuk mengadakan penelitian mengenai hubungan durasi waktu penggunaan TIK dengan kelebihan berat badan di SMAIT Nurul Fikri Depok. Penelitian ini bertujuan mengetahui hubungan durasi waktu penggunaan teknologi 
informasi dan komunikasi (TIK) dengan kelebihan berat badan pada siswa SMAIT Nurul Fikri Depok. Perangkat TIK diantaranya adalah mengakses sosial media, typing, dan blogging.

Hasil penelitian ini diharapkan mampu memberikan kontribusi terhadap pelayanan keperawatan komunitas, dan dapat dijadikan sebagai bahan dasar evidence based nursing practice (EBN) bagi pelayanan keperawatan untuk dapat meningkatkan upaya preventif dan promotif masalah durasi waktu penggunaan TIK berlebihan yang mengakibatkan kelebihan berat badan pada siswa SMA. Selain itu juga dapat memberikan pengetahuan, pengalaman dan wawasan terhadap pengembangan ilmu dan penelitian keperawatan komunitas dalam mengembangkan metode promosi kesehatan terkait perilaku sehat remaja untuk mencegah terjadinya perilaku kurang gerak yang bisa mengakibatkan kelebihan berat badan yang dapat mengancam kehidupan remaja. Manfaat penelitian lainnya yaitu menjadi dasar untuk penelitian keperawatan komunitas dan mampu mendorong inovasi dalam pelaksanaan penelitian yang terkait dengan topik durasi waktu penggunaan teknologi informasi dan komunikasi.

\section{METODE PENELITIAN}

Penelitian ini dilaksanakan di SMAIT Nurul Fikri Kota Depok. Penetapan lokasi penelitian didasarkan adanya fenomena, yaitu banyaknya siswa yang menggunakan TIK dalam kehidupan sehari-hari. Penelitian ini terdiri dari tahap persiapan, pelaksanaan, dan penyusunan laporan. Tahap persiapan dilaksanakan pada bulan Februari 2015. Tahap pelaksanaan meliputi perijinan, uji coba instrument, pengumpulan dan analisis data dilaksanakan pada bulan Maret-Mei 2015.

Perhitungan besar sampel dalam penelitian ini menggunakan rumus sebagai berikut:

$$
n=\frac{N}{1+N(d)^{2}}
$$

Keterangan:

$\mathrm{N}$ : besar populasi

$\mathrm{n}$ : besar sampel

$\mathrm{d}$ : deviasi dari prediksi proporsi (absolute precision) yang diinginkan

Rumus tersebut digunakan jika populasi kurang dari 10.000. Besarnya sampel siswa SMAIT Nurul Fikri Depok adalah 387 siswa. Peneliti menetapkan sebesar 5\% dengan tingkat kepercayaan yang dikehendaki adalah $95 \%$ dan presisi $10 \%$. Besarnya sampel dalam penelitian ini adalah sebagai berikut:

$$
\begin{aligned}
& {\left[n=\frac{387}{1+387(0.05)^{2}}\right]} \\
& \mathrm{n}=197 \text { siswa } \\
& \mathrm{n}=197+20 \\
& \mathrm{n}=217 \text { siswa }
\end{aligned}
$$

Penelitian ini menggunakan metode penelitian riset kuantitatif dengan desain deskriptif korelasional dengan pendekatan cross sectional. Sampel dalam penelitian sebanyak 217 responden ditentukan dengan menggunakan teknik purposive sampling terhadap siswa SMAIT Nurul Fikri Depok. Pengumpulan data dilakukan menggunakan kuesioner dan lembar observasi hasil pemeriksaan IMT. Data analisis menggunakan univariat dan bivariat, yaitu uji chi square.

\section{HASIL DAN PEMBAHASAN}

Karakteristik responden berada pada rentang remaja tengah (13-15 tahun) dan remaja akhir (16-19 tahun). Responden menggunakan TIK dalam kehidupan sehari-hari. 
Tabel 1. Distribusi Usia Siswa Orang Tua Siswa di SMAIT Nurul Fikri Depok $(n=217)$

\begin{tabular}{ccc}
\hline Variabel Usia & Frekuensi & Persentase (\%) \\
\hline Remaja Akhir (16-19 tahun) & 91 & 41.9 \\
\hline Remaja Tengah (13-15 tahun) & 126 & 58.1 \\
\hline Total & $\mathbf{2 1 7}$ & $\mathbf{1 0 0 . 0}$
\end{tabular}

Hasil distribusi data menunjukkan bahwa separuh siswa SMAIT Nurul Fikri Depok merupakan kelompok usia remaja tengah, yaitu sebesar $58.1 \%$. Jumlahnya tidak jauh berbeda antara kelompok usia remaja tengah dan usia remaja akhir. Hal ini dikarenakan dalam pengambilan sampel, jumlah sampel yang masuk dalam kelompok usia remaja tengah dan akhir hampir sama. Sampel dalam penelitian ini terdiri dari siswa SMA kelas 13, dimana rata-rata siswa memasuki usia remaja tengah dan akhir. Lebih dari separuh sampel penelitian adalah kelompok usia remaja tengah, dimana remaja tengah berada pada kelas 1 dan 2 SMA. Remaja akhir lebih sedikit dibandingkan kelompok remaja tengah karena usia remaja akhir didominasi oleh siswa kelas 2 dan 3 SMA. Siswa kelas 3 telah melaksanakan kegiatan Ujian Nasional (UN) sehingga siswa libur sekolah sampai pengumuman UN.

Pada penelitian ini menggunakan objek remaja usia 13-19 tahun dengan jumlah 217 responden. Tidak ada variabel yang paling dominan dalam mempengaruhi kelebihan berat badan remaja. Hal ini dikarenakan banyak faktor yang mempengaruhi berat badan seseorang, salah satunya adalah kurangnya aktivitas fisik seperti yang peneliti teliti. Penelitian ini hanya meneliti salah satu hipotesis tersebut, yaitu hipotesis peningkatan kurang gerak.

Menurut Wong (2009), remaja tengah dalam masa mengalami perubahan jasmani yang sangat pesat dan perkembangan intelektual yang sangat intensif sehingga minat remaja terhadap dunia luar sangat besar dan pada saat ini remaja tidak mau dianggap kanakkanak lagi. Kepribadian remaja pada masa ini masih kekanak-kanakan tetapi pada masa remaja ini timbul unsur baru yaitu kesadaran akan kepribadian dan kehidupan badaniah sendiri. Remaja mulai menentukan nilai-nilai tertentu. Remaja tengah ini cenderung mengikuti perilaku teman sebayanya. Sedangkan pada remaja akhir, remaja sudah mantap dan stabil. Remaja sudah mengenal dirinya dan ingin hidup dengan pola hidup yang digariskan sendiri dengan keberanian. Remaja mulai memahami arah hidupnya dan menyadari tujuan hidupnya. Remaja sudah mempunyai pendirian tertentu berdasarkan satu pola yang jelas yang baru ditemukannya. Remaja tengah dan akhir cenderung mengikuti perkembangan modern, yaitu menggunakan TIK dalam kehidupan sehari-hari. Bahkan menurut data KOMINFO tahun 2012 menyatakan bahwa remaja yang sedang duduk di bangku SMA menempati peringkat unggul dalam penggunaan TIK, yang kemudian disusul oleh remaja mahasiswa sebagai peringkat kedua penggunaan TIK.

Tabel 2. Distribusi Kelebihan Berat Badan Siswa di SMAIT Nurul Fikri Depok (n=217)

Kelebihan Berat $\quad$ Frekuensi $\quad$ Persentase (\%)
Badan

\begin{tabular}{lcc}
\hline Tidak & 153 & 70.5 \\
\hline Ya & 64 & 29.5 \\
\hline Total & $\mathbf{2 1 7}$ & $\mathbf{1 0 0 . 0}$ \\
\hline
\end{tabular}

Berdasarkan data kelebihan berat badan menunjukkan bahwa sebagian besar siswa SMAIT Nurul Fikri Depok tidak memiliki kelebihan berat badan, yaitu sebanyak $70.5 \%$. Sedangkan siswa yang memiliki kelebihan berat badan sebanyak $29.5 \%$. Jumlah siswa yang 
memiliki kelebihan berat badan lebih banyak dibandingkan dengan data RISKESDAS tahun 2013. Menurut data RISKESDAS 2013, Prevalensi gemuk pada remaja umur 16-18 tahun sebanyak $7.3 \%$ yang terdiri dari $5.7 \%$ gemuk dan $1.6 \%$ obesitas. Hal ini menunjukkan bahwa prevalensi siswa dengan kelebihan berat badan di SMAIT Nurul Fikri adalah cukup besar.

Di luar dugaan peneliti bahwa prevalensi kelebihan berat badan di SMAIT Nurul Fikri lebih besar dibandingkan data RISKESDAS 2013. Cukup besarnya prevalensi kelebihan berat badan ini berisiko terhadap dampak buruk akibat kelebihan berat badan, diantaranya adalah dampak kesehatan, psikososial, dan ekonomi. Tingginya angka kelebihan berat badan pada usia remaja akan meningkatkan risiko penyakit degeneratif pada usia dewasa. Faktor penyebab terjadinya kelebihan berat badan pada remaja sebagian besar disebabkan perilaku makan yang salah (tinggi energi, tinggi lemak, rendah serat makanan) dan perilaku hidup (aktivitas fisik yang rendah).

Dampak kesehatan diantaranya adalah secara statistik kematian yang disebabkan kelebihan berat badan dan kegemukan lebih besar jumlahnya dibandingkan kematian penduduk karena underweight (WHO, 2009). Dampak psikososial diantaranya adalah masyarakat cenderung memandang seseorang dengan kelebihan berat badan dan kegemukan itu tidak menarik, tidak indah dan akhirnya kurang menghargai orang tersebut karena orang tersebut dianggap tidak memiliki kemauan dan akhirnya akan berdampak pada perasaan minder, malu, merasa ditolak dan tertekan (NIH, 2012).

Tabel 3. Hubungan durasi waktu penggunaan akses sosial media dengan kelebihan berat badan siswa SMAIT Nurul Fikri Depok $(n=217)$

\begin{tabular}{cccccc}
\hline Durasi Waktu & \multicolumn{2}{c}{ Kelebihan berat badan } & Total & $\begin{array}{c}\text { OR } \\
(\mathbf{9 5 \%} \text { CI })\end{array}$ & P value \\
& Tidak & Ya & & & \\
\hline $\mathbf{5}$ jam & 16 & 1 & 17 & 7.358 & 0.026 \\
& $(94.1 \%)$ & $(5.9 \%)$ & $(100.0 \%)$ & $(0.955-56.709)$ & \\
$>\mathbf{5}$ jam & 137 & 63 & 200 & & \\
& $(68.5 \%)$ & $(31.5 \%)$ & $(100.0 \%)$ & & \\
Jumlah & 153 & 64 & & & \\
& $(70.5 \%)$ & $(29.5 \%)$ & & & \\
\hline
\end{tabular}

Berdasarkan tabel 3 menunjukkan ada hubungan yang signifikan antara durasi waktu penggunaan akses sosial media dengan kelebihan berat badan siswa SMAIT Nurul Fikri Depok.

Tabel 4. Hubungan durasi waktu penggunaan typing dengan kelebihan berat badan siswa SMAIT Nurul Fikri Depok $(n=217)$

\begin{tabular}{|c|c|c|c|c|c|}
\hline \multirow{2}{*}{$\begin{array}{l}\text { Durasi } \\
\text { Waktu }\end{array}$} & \multirow{2}{*}{\multicolumn{2}{|c|}{$\begin{array}{l}\text { Kelebihan berat } \\
\text { badan }\end{array}$}} & \multirow[t]{2}{*}{ Total } & \multirow{2}{*}{$\begin{array}{c}\text { OR } \\
(95 \% \mathrm{CI})\end{array}$} & \multirow[t]{2}{*}{ P value } \\
\hline & & & & & \\
\hline$<5$ iam & 19 & 2 & 21 & 4.396 & 0.042 \\
\hline & $(90.5 \%)$ & $(9.5 \%)$ & $(100.0 \%)$ & $(0.993-19.460)$ & \\
\hline$>5 \mathrm{jam}$ & 134 & 62 & 196 & & \\
\hline & $(68.4 \%)$ & $(31.6 \%)$ & $(100.0 \%)$ & & \\
\hline Jumlah & 153 & 64 & 217 & & \\
\hline & $(70.5 \%)$ & $(29.5 \%)$ & $(100.0 \%)$ & & \\
\hline
\end{tabular}

Berdasarkan tabel 4 menunjukkan hubungan yang signifikan antara durasi waktu penggunaan typing dengan kelebihan berat badan siswa SMAIT Nurul Fikri Depok. Siswa yang menggunakan typing lebih dari 5 jam mempunyai peluang 4.396 kali untuk memiliki 
kelebihan berat badan dibandingkan siswa yang menggunakan menggunakan typing kurang dari sama dengan 5 jam untuk memiliki kelebihan berat badan (95\% CI; OR = 0.993 ; 19.460). Hal ini ditunjang oleh data Samuel (2012) yang menunjukkan bahwa sebanyak $87.8 \%$ pengguna menggunakan akses sosial media di internet dan sebanyak $22.4 \%$ pengguna menggunakan chatting dalam penggunaan internet.

Tabel 5. Hubungan durasi waktu penggunaan blogging dengan kelebihan berat badan siswa SMAIT Nurul Fikri Depok $(n=217)$

\begin{tabular}{cccccc}
\hline $\begin{array}{c}\text { Durasi } \\
\text { Waktu }\end{array}$ & \multicolumn{2}{c}{ Kelebihan berat badan } & Total & $\begin{array}{c}\text { OR } \\
\mathbf{9 5 \%} \mathbf{C I})\end{array}$ & P value \\
& Tidak & Ya & & & \\
\hline $\mathbf{5}$ jam & 55 & 30 & 85 & 0.636 & 0.177 \\
& $(64.7 \%)$ & $(35.3 \%)$ & $(100.0 \%)$ & $(0.352-$ & \\
$>\mathbf{5}$ jam & 98 & 34 & 132 & $1.149)$ & \\
& $(74.2 \%)$ & $(25.8 \%)$ & $(100.0 \%)$ & & \\
Jumlah & 153 & 64 & 217 & & \\
& $(70.5 \%)$ & $(29.5 \%)$ & $(100.0 \%)$ & & \\
\hline
\end{tabular}

Berdasarkan tabel 5 hasil analisis hubungan durasi waktu penggunaan blogging dengan kelebihan berat badan pada siswa SMAIT Nurul Fikri Depok proporsi siswa yang menggunakan blogging $>5$ jam memiliki berat badan lebih sebanyak $25.8 \%$, sedangkan siswa yang menggunakan blogging $\leq 5$ jam memiliki berat badan lebih sebanyak $35.3 \%$. Hasil uji statistik diperoleh $\mathrm{p}$ value $>0.05$, maka dapat disimpulkan tidak ada hubungan yang signifikan antara durasi waktu penggunaan blogging dengan kelebihan berat badan siswa SMAIT Nurul Fikri Depok.

Sesuai penelitian ini hubungan durasi waktu penggunaan blogging dengan kelebihan berat badan menunjukkan tidak ada hubungan yang signifikan antara durasi waktu penggunaan blogging dengan kelebihan berat badan. Salah satu profil pengguna internet di Indonesia, menurut Asosiasi Pengguna Internet Indonesia (APII) dalam Samuel (2012) disebutkan bahwa seseorang mengakses TIK untuk blogging. Kegiatan blogging memang memerlukan waktu yang relatif lebih lama dibandingkan dengan typing. Akan tetapi kegiatan ini jarang dijadikan kegiatan leisure.

Penggunaan TIK yang diteliti adalah durasi waktu penggunaan akses sosial, typing, dan blogging. Penggunaan akses sosial media dan typing mempengaruhi kelebihan berat badan remaja. Penggunaan blogging tidak. Akan tetapi tidak ada hal yang sangat dominan mempengaruhi kelebihan berat badan. Hal ini mendukung penelitian yang dilakukan oleh San (2014) yang melakukan kajian hubungan antara body mass index (BMI) dengan durasi akses terhadap internet. Objeknya yaitu mahasiswa usia 19-24 tahun dengan jumlah sampel sebesar 525 orang. Aktifitas yang dilakukan yaitu akses internet. Hasil penelitian menunjukkan hasil yang signifikan antara kelebihan berat badan dengan nilai Bodi Mass Index pada mahasiswa.

Pada penelitian ini digunakan data berupa kegiatan yang dilakukan ketika seseorang mengakses TIK diantaranya mengakses terhadap sosial media, typing, blogging. Berdasarkan hasil penelitian ini menunjukkan bahwa pada saat ini remaja banyak menggunakan akses sosial media dibandingkan typing, dan blogging. Tingginya akses sosial media dapat menurunkan aktifitas fisik yang dilakukan seseorang. Aktivitas fisik merupakan salah satu faktor yang dapat meningkatkan kebutuhan energi, sehingga apabila aktivitas fisik rendah maka kemungkinan terjadinya kelebihan berat badan akan meningkat. Misalnya pada anak seperti berkurangnya lapangan tempat bermain serta tersedianya hiburan dalam bentuk game elektonik atau play station dan tontonan televisi (Nugraha, 2009). Kurangnya aktivitas 
fisik inilah yang menjadi penyebab kelebihan berat badan karena kurangnya pembakaran lemak dan sedikitnya energi yang dipergunakan (Mustofa, 2010). Aktivitas fisik berhubungan dengan kelebihan berat badan pada remaja. Di masa ini, penggunaan TIK sudah menjadi hal yang biasa bagi remaja. Remaja rela duduk berjam-jam di depan komputer menghabiskan waktu. Hal ini cenderung menimbulkan kurangnya aktivitas fisik. Remaja yang kurang melakukan aktivitas fisik sehari-hari menyebabkan tubuhnya kurang mengeluarkan energi. Jika asupan energi berlebih tanpa diimbangi aktivitas fisik yang seimbang maka seseorang remaja mudah mengalami kegemukan.

Selaras dengan penelitian tersebut, pada penelitian ini menunjukkan ada hubungan yang signifikan antara durasi waktu penggunaan akses sosial media dengan kelebihan berat badan siswa SMAIT Nurul Fikri Depok. Siswa yang menggunakan akses sosial media lebih dari 5 jam mempunyai peluang 7.358 kali untuk memiliki kelebihan berat badan siswa dibandingkan siswa yang menggunakan akses sosial media kurang dari sama dengan 5 jam untuk memiliki kelebihan berat badan siswa $(95 \% \mathrm{CI}$; OR $=0.955$; 56.709).

Penggunaan TIK selanjutnya yang diteliti adalah typing. Pada penelitian ini dapat disimpulkan ada hubungan yang signifikan antara durasi waktu penggunaan typing dengan kelebihan berat badan siswa SMAIT Nurul Fikri Depok. Siswa yang menggunakan typing kurang dari 5 jam mempunyai peluang 4.396 kali untuk membentuk kelebihan berat badan siswa. Menurut Sari \& Aydin (2014) salah satu aktifitas yang banyak dilakukan ketika seseorang mengases TIK yaitu penggunaan typing.

Tingginya akses sosial media dapat menurunkan aktifitas fisik yang dilakukan seseorang. Aktivitas fisik merupakan salah satu faktor yang dapat meningkatkan kebutuhan energi, sehingga apabila aktivitas fisik rendah maka kemungkinan terjadinya kelebihan berat badan akan meningkat. Misalnya pada anak seperti berkurangnya lapangan tempat bermain serta tersedianya hiburan dalam bentuk game elektonik atau play station dan tontonan televisi (Nugraha, 2009). Kurangnya aktivitas fisik inilah yang menjadi penyebab kelebihan berat badan karena kurangnya pembakaran lemak dan sedikitnya energi yang dipergunakan (Mustofa, 2010). Aktivitas fisik berhubungan dengan kelebihan berat badan pada remaja. Di masa ini, penggunaan TIK sudah menjadi hal yang biasa bagi remaja. Remaja rela duduk berjam-jam di depan komputer menghabiskan waktu. Hal ini cenderung menimbulkan kurangnya aktivitas fisik. Remaja yang kurang melakukan aktivitas fisik sehari-hari menyebabkan tubuhnya kurang mengeluarkan energi. Jika asupan energi berlebih tanpa diimbangi aktivitas fisik yang seimbang maka seseorang remaja mudah mengalami kegemukan.

Perkembangan TIK yang semakin cepat mendorong perubahan pola kehidupan manusia ke arah pola hidup modern, mulai dari kantor, rumah, pasar, dan sekolah. Perkembangan TIK juga merambah dari TIK yang bersifat tradisional ke arah TIK modern. Pada abad ke-20, tepatnya antara tahun 1910-1920, terwujud sebuah transmisi suara tanpa kabel melalui siaran radio AM yang pertama. Komunikasi suara tanpa kabel ini pun segera berkembang pesat. Kemudian diikuti pula oleh transmisi audio-visual tanpa kabel, yang berwujud siaran televisi pada tahun 1940-an. Dalam 10 tahun terakhir ini, yaitu setelah masuk era millennium, Internet di Indonesia berkembang sangat pesat, yang ditandai oleh perkembangan pada berbagai aspek. Samuel (2012) dalam The profile of Indonesia's Internet Users mengungkapkan karakteristik dan behavior penggunanan internet di Indonesia. Pada awalnya, internet hanya bisa dinikmati secara fixed (di tempat yang diam) saja, misalnya perangkat komputer desktop. Namun, secara perlahan-lahan Internet hadir dalam bentuk yang lebih dinamis dan praktis. Di mana internet bisa diakses lewat beragam perangkat yang bisa dibawa ke mana saja. Seperti melalui smartphone, laptop atau netbook ataupun perangkat komputer tablet.

Lingkungan modern serta perkembangan teknologi yang cepat khususnya TIK merubah cara hidup manusia. Manusia cenderung memiliki aktifitas fisik lebih sedikit. Aktifitas fisik 
yang rendah dapat berakibat pada peningkatan berat badan, apalagi jika disertai dengan intake berlebihan. Beberapa penelitian menunjukkan terdapat hubungan antara penggunaan TIK dengan kelebihan berat badan, sementara beberapa penelitian yang lain menunjukkan hasil sebaliknya, yaitu tidak terdapat hubungan antara penggunaan TIK dengan kelebihan berat badan.

Penelitian yang menunjukkan hasil positif antara TIK dan kelebihan berat badan diantaranya penelitian yang dilakukan oleh Kim (2010) yang menunjukkan terdapat hubungan antara kelebihan berat badan dan penggunaan TIK berlebih khususnya internet. Pada penelitian ini juga menunjukkan bahwa penggunaan TIK berakibat pada perubahan gaya hidup dan pola makan.

Penelitian yang menunjukkan hasil positif antara TIK dan kelebihan berat badan diantaranya penelitian yang dilakukan oleh Kim (2010) yang menunjukkan terdapat hubungan antara kelebihan berat badan dan penggunaan TIK berlebih khususnya internet. Pada penelitian ini juga menunjukkan bahwa penggunaan TIK berakibat pada perubahan gaya hidup dan pola makan. Pada penelitian ini lebih menunjukkan bahwa remaja cenderung menjadi seorang IA (Internet Addiction) sehingga mengurangi aktifitas fisik. Sementara pada penelitian Sari dan Aydin (2014), menggunakan mahasiswa sebagai objek. Hasilnya menunjukkan hubungan antara penggunaan internet berlebih dan TIK. Menurut Victor (2010), beberapa faktor yang dapat menyebabkan obesitas diantaranya yaitu intake berlebihan, aktifitas fisik dan metabolism rate. Faktor-faktor tersebut akan saling menguatkan jika seseorang memiliki intake yang tinggi dengan aktifitas fisik yang rendah disertai metabolisme yang rendah.

Gaya hidup pada remaja diantaranya adalah aktif di dunia internet. Menurut Sungiardi (2012) siswa SMA banyak menjadi pengguna internet di Indonesia dan gemar mengakses media sosial dengan menggunakan perangkat smartphone yang tidak terlalu rumit digunakan, harga perangkat dan biaya akses prabayar yang relatif terjangkau, sehingga mendukung budaya silaturahmi masyarakat Indonesia. Terdapat hal positif yang bisa diambil dari banyaknya remaja sebagai pengguna internet, diantaranya adalah perawat komunitas bisa membuat fan page di facebook yang gemar dikunjungi oleh para pengguna atau membuat group-group di whatsapp, BBM, instagram, atau line yang memungkinkan para pengguna, khususnya remaja ikut aktif dalam group tersebut. Sehingga, penyebarluasan informasi tentang masalah kesehatan dapat tersampaikan dengan baik. Apabila ditelusuri ke tahun-tahun belakang, ternyata sudah ada website yang berisikan informasi kesehatan, akan tetapi para pengguna internet kurang interest terhadap website tersebut. Hal ini dimungkinkan kurang menariknya website tersebut ataupun website terlalu banyak tulisan, sehingga remaja enggan untuk mengunjunginya.

Suatu data menunjukkan bahwa aktifitas fisik remaja cenderung menurun. Aktifitas meliputi aktifitas sehari-hari, kebiasaan, hobi, maupun latihan dan olahraga. Remaja yang kurang atau enggan melakukan aktifitas fisik menyebabkan tubuh kurang menggunakan energi yang tersimpan di dalam tubuh. Oleh karena itu, jika asupan energi berlebihan tanpa diimbangi aktifitas fisik yang sesuai maka dapat mengakibatkan obesitas. Padahal cara yang paling mudah dan umum dipakai untuk meningkatkan pengeluaran energi adalah dengan melakukan kegiatan fisik. Sebaliknya menggunakan TIK akan menurunkan aktifitas fisik dan keluaran energi karena mereka menjadi jarang atau kurang berjalan, bersepeda, maupun naik turun tangga.

Sebagian besar siswa SMAIT Nurul Fikri Depok tidak memiliki kelebihan berat badan, yaitu sebanyak $70.5 \%$. Sedangkan siswa yang memiliki kelebihan berat badan sebanyak $29.5 \%$. Jumlah siswa yang memiliki kelebihan berat badan lebih banyak dibandingkan dengan data RISKESDAS tahun 2013. Menurut data RISKESDAS 2013, Prevalensi gemuk pada remaja umur 16-18 tahun sebanyak $7.3 \%$ yang terdiri dari 5.7\% gemuk dan $1.6 \%$ 
obesitas. Hal ini menunjukkan bahwa prevalensi siswa dengan kelebihan berat badan di SMAIT Nurul Fikri adalah cukup besar.

Di luar dugaan peneliti bahwa prevalensi kelebihan berat badan di SMAIT Nurul Fikri lebih besar dibandingkan data RISKESDAS 2013. Cukup besarnya prevalensi kelebihan berat badan ini berisiko terhadap dampak buruk akibat kelebihan berat badan, diantaranya adalah dampak kesehatan, psikososial, dan ekonomi. Dampak kesehatan diantaranya adalah secara statistik kematian yang disebabkan kelebihan berat badan dan kegemukan lebih besar jumlahnya dibandingkan kematian penduduk karena underweight (WHO, 2009). Dampak psikososial diantaranya adalah masyarakat cenderung memandang seseorang dengan kelebihan berat badan dan kegemukan itu tidak menarik, tidak indah dan akhirnya kurang menghargai orang tersebut karena orang tersebut dianggap tidak memiliki kemauan dan akhirnya akan berdampak pada perasaan minder, malu, merasa ditolak dan tertekan (NIH, 2012). Dampak ekonomi diantaranya adalah meningkatnya risiko penyakit berbanding lurus dengan peningkatan biaya kesehatan yang harus ditanggung individu dan keluarga dengan kelebihan berat badan dan kegemukan (Kopelman, 2007).

Perawat komunitas seharusnya peduli terhadap masalah durasi waktu penggunaan TIK pada remaja yang beresiko terhadap kelebihan berat badan. Perawatan Kesehatan Masyarakat (perkesmas) dilakukan dengan mengutamakan pelayanan promotif dan preventif secara berkesinambungan tanpa mengabaikan pelayanan kuratif dan rehabilitatif secara menyeluruh dan terpadu, ditujukan kepada individu, keluarga, kelompok, sekolah, dan masyarakat untuk ikut meningkatkan fungsi kehidupan manusia secara optimal sehingga mandiri dalam upaya kesehatannya.

Sampai dengan saat ini masyarakat belum mengoptimalkan manfaat pelayanan puskesmas dan puskesmas pembantu (pustu) meskipun ada di setiap kecamatan. Keadaan ini semakin dipersulit dengan masih terbatasnya jumlah sumber daya manusia baik dari aspek kuantitas maupun kualitasnya. Perawat komunitas, dalam hal ini perawat komunitas dapat menjalankan perannya secara aktif dalam promosi kesehatan apabila dilaksanakan oleh tenaga perawat yang telah mendapatkan ilmu pengetahuan terkait promosi kesehatan. Hal ini bisa dilaksanakan oleh perawat dengan jenjang pendidikan S1 Ners. Masih sedikitnya perawat yang berpendidikan S1 Ners yang berada di bagian perkesmas. Secara umum, masih banyak perawat berjenjang pendidikan D3 yang melakukan kegiatan perkesmas ini.

Berdasarkan penelitian ini, bentuk kegiatan perkesmas yang bisa dilaksanakan adalah pengkajian keperawatan pasien sebagai deteksi dini (sasaran prioritas), penyuluhan kesehatan, dan konseling keperawatan. Deteksi dini bisa dilakukan melalui kegiatan screening terhadap durasi waktu penggunaan TIK siswa SMA dan berat badan secara berkala sehingga siswa mempunyai kartu kesehatan. Hal ini dilakukan melalui kerja sama dengan UKS yang berada di SMA. Akan tetapi, di sekolah tempat penelitian ini belum terdapat UKS. Sehingga, alangkah lebih baik untuk mengaktifkan kembali fungsi UKS di SMA. Penyuluhan kesehatan dapat dilakukan dengan menggunakan media yang menarik, sehingga siswa tertarik terhadap media tersebut.

Berdasarkan penelitian ini, sebagian besar siswa menggunakan TIK dalam kehidupan sehari-hari dan banyak diantaranya menggunakannya lebih dari 5 jam dalam sehari. Hal ini merupakan peluang bagus perawat dalam merancang media promosi kesehatan. Perancangan media ini bisa dilakukan oleh perawat dengan jenjang pendidikan S1 Ners dimana perawat tersebut telah dibekali ilmu pengetahuan untuk mampu mendesain media supaya menarik dan interaktif. Tindakan konseling kesehatan juga bisa dilaksanakan melalui TIK dimana banyak siswa yang menggunakan TIK dalam kehidupan sehari-hari. Sehingga, konseling kesehatan ini tidak harus dilakukan melalui tatap muka. Tetapi bisa dilaksanakan melalui dunia maya.

Peran perawat komunitas sangat dibutuhkan untuk memberikan pengetahuan kepada 
remaja supaya dapat merubah persepsi yang masih kurang baik terhadap durasi waktu penggunaan TIK yang beresiko pada kelebihan berat badan. Terutama pada penelitian ini adalah mengenai persepsi keseriusan dan kerentanan remaja tentang durasi penggunaan TIK yang berisiko terhadap kelebihan berat badan. Remaja, orang tua, dan guru dapat diberikan informasi mengenai dampak durasi waktu penggunaan TIK berlebihan yang beriko terhadap terjadinya kelebihan berat badan untuk meningkatkan persepsi keseriusan dan kerentanan pada kelebihan berat badan remaja. Program perkesmas dengan dilakukan oleh perawat berpendidikan S1 Ners sangat dibutuhkan dalam mendesain media promosi kesehatan supaya lebih interaktif. Promosi kesehatan dapat dilakukan dengan menggunakan media TIK yang berdasarkan penelitian ini banyak digunakan oleh siswa dalam kehidupan sehari-hari. Sehingga promosi kesehatan dapat tersampaikan tepat sasaran. Hal ini ditunjang oleh media informasi yang menarik.

\section{SIMPULAN}

Penelitian ini memberikan kesimpulan bahwa terdapat hubungan antara penggunaan akses sosial media dan penggunaan typing dengan kelebihan berat badan remaja. Tidak terdapat hubungan antara penggunaan blogging dengan kelebihan berat badan remaja.

Penelitian ini hanya menggunakan aktifitas fisik yang rendah sebagai variabel independennya, yaitu durasi waktu penggunaan TIK. Intake berlebihan dan metabolism rate tidak diteliti oleh peneliti pada penelitian ini. Sehingga tidak mendukung faktor yang paling berpengaruh terhadap keebihan berat badan. Secara keseluruhan, pada penelitian ini berhasil menunjukkan bahwa durasi waktu penggunaan TIK di SMAIT Nurul Fikri Depok tidak memberikan dampak yang signifikan terhadap kelebihan berat badan pada siswa. Hal ini karena ada faktor lain yang mempengaruhinya, yaitu intake makanan dan metabolism rate.

Hasil penelitian ini juga menunjukkan bahwa sebagian besar siswa menggunakan TIK dalam kehidupan sehari-hari. Bahkan ada beberapa TIK yang digunakan dalam waktu lebih dari 5 jam dalam sehari. Hal ini dapat dijadikan acuan dinas pendidikan untuk memberikan kebijakan kepada sekolah-sekolah terhadap siswanya untuk menonaktifkan handphone pada saat sekolah. Pada saat ini handphone bisa digunakan untuk melakukan berbagai macam kegiatan TIK.

Hasil penelitian ini dapat menjadi motivasi bagi guru dan keluarga siswa untuk lebih memperhatikan durasi waktu penggunaan TIK dan berat badan siswa secara bijak. Hal ini ditujukan supaya tidak menimbulkan berbagai macam penyakit di kemudian hari. Selain itu juga memperhatikan intake makanan dan aktivitas fisik lainnya remaja.

\section{SARAN}

Hasil penelitian dapat menjadi masukan bagi Dinas kesehatan dan puskesmas untuk lebih mengoptimalkan program perkesmas supaya pelayanan kesehatan kepada masyarakat, khususnya remaja dapat lebih bermutu dan berkualitas. Perawat S1 Ners dibutuhkan karena perawat yang bisa meng-update kemampuan mendesain promosi kesehatan sehingga media yang digunakan bisa lebih interaktif. Selain itu, Dinas Kesehatan perlu mengalokasikan anggaran untuk meningkatkan motivasi dan keterampilan perawat dalam rangka memberikan pendidikan kesehatan remaja, juga promosi kesehatan terkait kelebihan berat badan. Misalnya, melakukan workshop dan pelatihan perkesmas secara rutin setiap tahun sekali. Selain itu peneliti menyarankan kepada sekolah untuk mengaktifkan kembali program UKS di SMA supaya kesehatan siswa dapat terkontrol dengan baik dan adanya kebijakan terkait penggunaan TIK di sekolah, khususnya sosial media. 


\section{DAFTAR PUSTAKA}

Allender, J., Rector, C., \& Warner, K. (2014). Community \& Public Health Nursing: Promoting and protecting the Public's Health (8th ed.). New York: Lippincot Williams\&Wilkins

American Nurse Practitioner Foundation . (2013). Nurse Practitioners and the prevention and treatment of adult obesity. Austin: American Nurse Practitioner Foundation

Anderson, B., Rafferty, A. P., Callo, S. L., Fussman, C., \& Imes, G. (2011, July). Fast Food Consumption and Obesity Among Michigan Adults

Anderson, E. T., \& McFarlane, J. (2010). Community as partner: theory and practice in nursing. Philadelphia: Wolters Kluwer Health/Lippincott Williams \& Wilkins.

Anderso Craig. A , B. Funk Jeanne., D. Griffiths Mark. (2004). Contemporary issues in adolescent video game playing:brief overview and introduction to the special issue. Journal of Adolescence, 1-3

Becker, Marshall.H, 1974. The Health Belief Model and Personal Health Behaviour, School of Medicine and Hygiene and Public Health. Baltimore, Maryland

Budiyanto, Hendry. (2009). Perbedaan Frekuensi Makan dan Status Gizi pasien TB Paru sebelum dan sesudah diberikan Konseling Gizi di Balai Besar kesehatan Paru Masyarakat (BBKPM) Surakarta. Skrisi Program Studi Ilmu Gizi. Fakultas Ilmu Kesehatan. Universitas Muhammadiah Surakarta. Surakarta.

Burns, N \& Grove, S. (2009). The practice of nursing research: appraisal synthesis and generation of evidence. $6^{\text {th }}$ edition. St. Louis Saunders Elsevier

Gregory, J. Norman, PhD. et al., (2005). Psychosocial and Environmental Correlates of Adolescent Sedentary Behaviors.Pediatrics, vol 116, No. 4. Available at www.pediatricsdigest.org. Diakses tanggal 7 Nopember 2014

Hadi (2005). Hubungan Aktivitas Fisik, Kebugaran Fisik dan Imej Tubuh dengan Kejadian Obesitas pada Siswa SMA di Kota Banda Aceh. Sekolah Pascasarjana Universitas Gajah Mada.

Hayati, Mardhiyah. (2014). Analisis Faktor Orang Tua terhadap status Gizi balita pendekatan Teori Health Belief Model. Skripsi Program Studi Pendidikan Keperawatan. Fakultas Keperawatan. Universitas Airlangga. Surabaya

Hayden, J. A., \& Paterson, W. (2013). Introduction to Health Behavior Theory. Jones and Barlett Publishing.

Hockenbery, M.J \& Wilson. D. (2008). Wong's essentials pediatric nursing. Eight edition. St. Louis Missouri. Mosby. Inc

HSE. (2013). health survey for england. London: The Health and Sosial Care Information Centre.

Hudha, Luthfiana Arifatul. (2006). Hubungan Antara Pola Makan dan Aktivitas Fisik dengan Obesitas Pada Remaja Kelas I SMP Theresiana I Yayasan Bernadus Semarang [Skripsi]. Semarang : Teknologi Jasa dan Produksi FT Universitas Negeri Semarang

Kesaraporn Wanajak. (2011). Internet use and Its impact on secondary school students in Chiang Mai Thailand. PhD Dissertation. Faculty of Computing, Health and Science. Edith Cowan University. Thailand.

Kim Yeonsoo, Jin Young Park, Sung Byuk Kim, In-Kyung Jung, Yun Sook Lim and JungHyun Kim. (2010). The effects of Internet addiction on the lifestyle and dietary behavior of Korean adolescents. Nutrition Research and Practice (Nutr Res Pract), 51-57

Klesge C Robert, Shelthon L Mary, and Klesges M Lisa. (1993). Effects of television on metabolic rate: potential implication for childhood obesity. Pediatrics, 281-286

Mark Amy E., Janssen Ian. (2008). Relationship between screen time and metabolic syndrome in adolescents. Journal of Public Health, Vol. 30, No. 2, pp. 153-160

Martin, James. (1990). Information Engineering Planning \& Analysis, Book II. Prentice Hall International Inc, New Jersey 
Mota Jorge, Ribeiro Jose, Paula Santos Maria, and Helena Gomes. (2006). Obesity, Physical Activity,Computer Use, and TV Viewingin Portuguese Adolescents. Pediatric Exercise Science, 113-121

Mustofa, A., 2010. Solusi Ampuh Mengatasi Obesitas Disertai Pembahasan Tentang Sebab, Akibat dan Solusi Mengenai Obesitas. Yogyakarta: Hanggar Kreator.

Nanang Martono. (2010). Metode Penelitian Kuantitatif: Analisa isi dan Analisis data sekunder. Jakarta. Raja Grafindo Persada.

Oguna Abuodin, Iwenjiora Zoputanb, Jesutise Utibec, Ogechukwukana Chukwudimmac. (2014). The effect of Information and Communication Technology on the Prevalence of Obesity as well as Prominent Blood Pressure among Secondary School Students in Nigeria. International Journal of Research in Applied Sciences, 35-38

Polit, D. F., \& Beck, C. T. (2012). Nursing research: generating and assessing evidence for nursing practice. Philadelphia: Lippincott Williams \& Wilkins.

Pollit, D.F., \& Hungler, B.P. (2010). Nursing research: Principles and methods.edition. Philidelphia : Lippincott William \& Wilkins

Rikesdas. (2013). Riset kesehatan dasar laporan nasional 2013. Jakarta: Badan Penelitian Dan Pengembangan Kesehatan Departemen Kesehatan, Republik Indonesia

Samuel A, (2012). Profil pengguna internet di Indonesia. Asosiasi Pengguna Internet Indonesia (APII). Jakarta

Sartika, R Ayu Dewi. (2011). Faktor Risiko Obesitas pada Anak 5 - 15 Tahun di Indonesia.Makara, Kesehatan, Vol.15, No.1, Juni 2011: 37,43. Available at www.journal.iu.ac.id. Diakses tanggal 7 Nopember 2014

Sastroasmoro \& Ismail. (2010). Dasar-dasar metodologi penelitian klinis. (Edisi kedua). Jakarta: CV. Sagung Seto.

Snoek Harriette M., Tatjana van Strien, Jan M.A.M. Janssens, and Rutger. (2006). The Effect of Television Viewing on Adolescents' Snacking: Individual Differences Explained by External, Restrained and Emotional Eating. Journal of Adolescent Health, 448-451

Stanhope, Lancaster. (2010). Community Health Health Nursing, 4 th Ed. St Louis Missouri: Mosby Co

Subrahmanyam Kaveri, E. Kraut Robert, M. Greenfield Patricia, \& F. Gross Elisheva. (2000). The Impact of Home Computer Use on Children's Activities and Development. The Future of Children CHILDREN AND COMPUTER TECHNOLOGY, 123-144

Sungiardi, Michael. (2012) Profil Demografis Internet Indonesia. Asosiasi Pengguna Internet Indonesia (APII). Jakarta.

Sugiyono, 2008. Statistika untuk Penelitian. Bandung : Alfabeta.

Soetjiningsih, (1998). Tumbuh Kembang Anak. Laboratorium Ilmu Kedokteran Anak Universitas Air Langga, Surabaya.

Sjarif, D., R.., 2011. Obesitas Anak dan Remaja. Dalam: Sjarif, D., R., Lestari, E., D.,Mexitalia, M., Nasar, S., S. Buku Ajar Nutrisi Pediatrik dan Penyakit Metabolik.Jakarta: IDAI

Tata Sutabri. 2014. Sistem Informasi Manajemen, Penerbit Andi, Yogyakarta.

Tsitsika Artemis, Critselis Elena, Louizou Amalia, Janikian Mari, Freskou Aliki, Marangou Evgenia, Kormas Georgios, and Dimitrios A. Kafetzis. (2011). Determinants of Internet Addiction among Adolescents: A Case-Control Study. TheScientificWorldJOURNAL, 866874

WHO. (2009). Obesity and overweight: WHO Global Strategy on Diet, Physical Activity and Health. Geneva. World Health Organization. 